\title{
Ammonia-oxidizing bacteria and archaea within biofilters of a commercial recirculating marine aquaculture system
}

\author{
Zhitao Huang ${ }^{1 \dagger}$, Yuli Jiang ${ }^{1 \dagger}$, Xiefa Song ${ }^{1}$, Eric Hallerman ${ }^{2 *}$, Lei Peng ${ }^{1}$, Dengpan Dong ${ }^{1}$, Teng $\mathrm{Ma}^{3}$, \\ Jieming Zhai ${ }^{4}$ and Wensheng $\mathrm{Li}^{4}$
}

\begin{abstract}
While biofilters are widely used to metabolize ammonia and other wastes in marine recirculating aquaculture systems, the ammonia-oxidizing bacterial and archaeal communities have not been characterized across a diversity of production systems. Using a metagenomics approach, we characterized the ammonia-oxidizing microbiological community of biofilters in a commercial recirculating marine aquaculture system producing hybrid grouper (Epinephelus lanceolatus $\times$ E. fuscoguttatus). Cloning and sequencing of the amoA gene showed that nitrifying bacteria included Nitrosomonas europea, N. stercoris, N. cryotolerans, N. eutropha, N. estuarii, eight strains of N. marina, and 15 strains not associated with described species. Nitrifying archaea included eight strains of Nitrosopumilus maritimus, N. koreensis, N. piranensis, N. adriaticus, undescribed congeners, and other undescribed archaea. The species composition of the bacterial and especially the archaeal communities was beyond that yet reported for aquaculture biofilters. While ammonia flux through the respective communities has yet to be estimated, the diverse environmental adaptations of the bacterial and archaeal communities suggest resilience of function under a range of environmental conditions.
\end{abstract}

Keywords: Water quality, Growth, Microbial community, Recirculating aquaculture system, Hybrid grouper Epinephelus lanceolatus $\times$ E. fuscoguttatus, Metabarcoding

\section{Introduction}

Effective biological filtration is critical to fish production in a recirculating aquaculture system (RAS). Classical characterization of biological filtration involves measurement of chemical parameters (e.g., ammonia, nitrite, and nitrate concentrations, biochemical oxygen demand), and culture-based identification of key species within the microbial consortium. Chemolithotrophic ammoniaoxidizing bacteria (AOB) grow only very slowly, however, and are more difficult to detect in the biofilm than the more-common Nitrosomonas and Nitrosococcus species. With the advent of metagenomic analyses, the latter may also involve molecular genetic characterization

\footnotetext{
*Correspondence: ehallerm@vt.edu

†Zhitao Huang and Yuli Jiang contributed equally to this work and should be considered co-first authors

${ }^{2}$ Department of Fish and Wildlife Conservation, Virginia Polytechnic

Institute and State University, Blacksburg, VA 24061, USA

Full list of author information is available at the end of the article
}

of the microbial community of the biofilm in the biofilter. That is, species-specific DNA sequences-most often of the $16 S$ rRNA gene-may be amplified, sequenced, and screened against a genomic database to identify the microbes in the biofilm (e.g., Schreier et al. 2010; Huang et al. 2016). An enzyme unique to chemolithotrophic ammonium-oxidizing microbes (McTavish et al. 1993; Bergmann and Hooper 1994) is ammonia monooxygenase $(a m o A)$, which oxidizes ammonia to the intermediate hydroxylamine (Wood 1986); although the enzyme also oxidizes other substrates (Bock et al. 1986; Hooper 1989), amoA is a useful target DNA sequence for detecting and identifying ammonium-oxidizing microbes in environmental samples. Polymerase chain reaction (PCR) assays that target the $a m o A$ gene are sufficiently sensitive and non-specific to detect a broad range of microbes containing the enzyme in environmental samples (Sinigalliano et al. 1995). While studies of ammonia-oxidizing microbial communities of aquaculture biofilters have 
been executed (Tal et al. 2003; Sugita et al. 2005; Itoi et al. 2006; Foesel et al. 2008; Urakawa et al. 2008; Schreier et al. 2010; Sauder et al. 2011; Keuter 2011; Sakami et al. 2012; Blancheton et al. 2013; Brown et al. 2013; Kruse et al. 2013; Bagchi et al. 2014; Rurangwa et al. 2014; Michaud et al. 2014; Ruan et al. 2015; Gonzalez-Silva et al. 2016; Huang et al. 2016; Lee et al. 2016; Bartelme et al. 2017; Keuter et al. 2017), molecular genetic and bioinformatic tools as well as DNA sequence archives for bacterial characterization have improved recently, especially for ammonia-oxidizing microbes. Further, characterization of a broader range of marine RAS would deepen our insight into microbial community structure and function under a range of culture conditions.

Groupers (subfamily Epinephelinae, family Serranidae) comprise a diverse group of predatory fishes widely distributed through tropical and subtropical seas, and have become an important aquaculture product. In China alone, captive production of groupers in 2014 totaled 88,130 metric tons (Fishery Bureau 2015). Hybrid tiger (Epinephelus fuscoguttatus) $\times$ giant (E. lanceolatus) grouper exhibit rapid growth, thick fillet, high collagen content in meat, and strong disease resistance (Ch'ng and Senoo 2008), and has been commercialized globally (Senoo 2010; Wang et al. 2015). Production is carried out in flow-through systems (Wang et al. 2004), highly intensive culture ponds (Li et al. 2013), and more recently in recirculating aquaculture systems (Yang et al. 2016).

We previously characterized and compared the microbial communities of nine biofilters in five commercial marine recirculating marine aquaculture systems by amplifying and sequencing the $16 \mathrm{~S}$ ribosomal RNA (rRNA) gene (Huang et al. 2016). Within the nitrifying community of three biofilters at Laizhou Mongbao Aquatic Co., Ltd., our results showed relatively frequent observations of Nitrosomonas sp. (1.1-2.9\%) and Nitrospira sp. (0.5-7.1\%). Ammonia being the more toxic nitrogenous waste to fishes, we aimed in this study to focus more closely on the critical ammonia-oxidizing community. Hence, we chose to sequence the ammonia monooxygenase $(a m o A)$ gene, identifying the respective bacterial and also archaeal hosts by searching our sequence results against archived $a m o A$ sequences. Our results revealed a diversity of ammonia-oxidizing bacteria and especially archaea not heretofore known in aquaculture biofilters. We discuss the diversity of species and their respective environmental optima with respect to the resilience of biofilm function under fluctuating production and environmental conditions.

\section{Methods and materials}

\section{System description}

The commercial RAS at Laizhou Mingbo Aquatic Co., Ltd. (Fig. 1) contained 16 fish-rearing tanks that were 7 - $\mathrm{m}$ inner diameter $\times 1.0 \mathrm{~m}$-deep. The tanks were filled to depths of $0.8-0.9 \mathrm{~m}$, yielding a water volume in each tank of approximately $33 \mathrm{~m}^{3}$. Water was pumped through two 5-cm inner-diameter nozzles above each tank. Water level in each tank was controlled by an outside standpipe connected to the bottom drain. The effluent from the bottom of the tanks first passed through a bowed screen with $0.25-\mathrm{mm}$ screen sieves to remove suspended solids; the filtrate on the screen was removed manually with high-pressure water about $30 \mathrm{~min}$ after feeding. The water then passed through a foam fractionator (3 m diameter $\times 3 \mathrm{~m}$ height, $2.5 \mathrm{~m}$ water depth) to remove fine solids. A series of three submerged biofilters $(3 \mathrm{ml} \times 3 \mathrm{~m} \mathrm{~W} \times 5 \mathrm{~m} \mathrm{H}$ each) containing elastic polyolefin media bio-media $\left(100 \mathrm{~m}^{2} / \mathrm{m}^{3}\right)$ treated ammonia and other metabolic waste products. An ultraviolet light

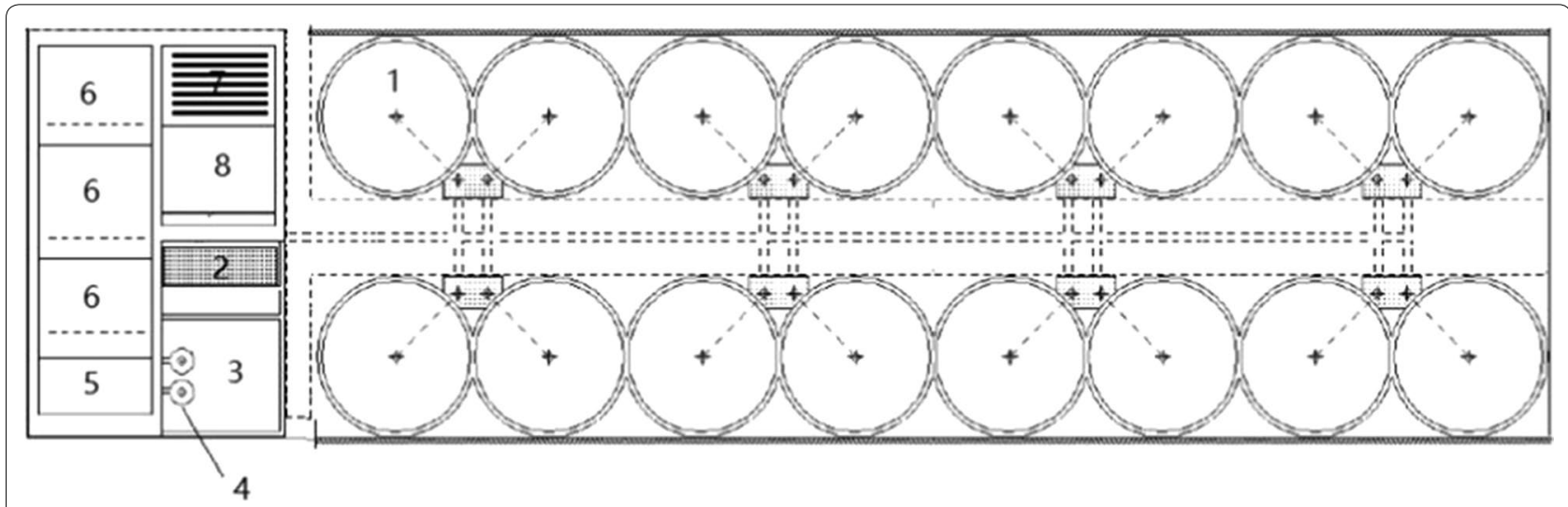

Fig. 1 Schematic diagram for RAS producing hybrid grouper (Epinephelus lanceolatus $\times$ E. fuscoguttatus) at Laizhou Mingbo Aquatic Co. The units are: (1) 16 fish rearing tanks, (2) a bowed screen, (3) a sump, (4) two pumps, (5) foam fractionators, (6) series of three biofilters, (7) UV disinfection unit, and (8) dissolved oxygen contact unit 
chamber unit with 1655 -W lamps inactivated heterotrophic and coliform bacteria. Micropore diffusers (Tean Technology Co., Ltd., Nanjing, China) injected pure oxygen into the contact unit, and treated water flowed back to the rearing tanks by gravity.

\section{Fish culture}

19,200 hybrid groupers (1200 per tank) were stocked into the RAS for 240 days (April 4th to November 23rd, 2013) for on-growing to harvest size. Initial mean weight was $156.3 \pm 11.8 \mathrm{~g} /$ fish, mean length was $20.9 \pm 1.4 \mathrm{~cm}$, and stocking density was $6.08 \mathrm{~kg} / \mathrm{m}^{3}$. The fish were hand-fed a commercial diet containing $45 \%$ protein and 16\% lipid at $1.2-1.5 \%$ body weight/day for the first 2 months, and $1 \%$ body weight/day thereafter.

Thirty to fifty fish per tank were randomly sampled monthly to determine body weight gain, length gain, specific growth rate, and feed conversion rate. Total ammonia was analyzed weekly using the phenate method and nitrite using the sulfanilamide-NED method (APHA et al. 1995). Temperature and dissolved oxygen were monitored daily using a YSI 85 probe (YSI, Inc., Yellow Springs, OH, USA). pH was measured daily using a YSI pH100m (YSI Inc., Yellow Springs, OH).

\section{Characterization of biofilter microbial communities}

Bio-media from each unit in the series of submerged biofilters were cut into small pieces, and the microbial film was suspended in phosphate-buffered saline solution. After centrifugation at $14,000 \mathrm{~g}$ for $10 \mathrm{~min}$, each supernatant was collected for DNA extraction using the FastDNA Spin Kit for Soil (MP Biomedicals, Illkirch, France) using to the manufacturer's protocols. The quantity and quality of the extracted DNA were measured using an ND-2000 spectrophotometer (Nanodrop, Inc., Wilmington, DE, USA).

To characterize the ammonia-oxidizing bacterial and archaeal communities, DNA samples were amplified, cloned, and sequenced. The 491-bp fragments of bacterial amo $A$ genes and the 635-bp fragments of archaeal $a m o A$ genes were amplified using the PCR primers and amplification conditions shown in Table 1. Replicate amplifications were pooled and purified by gel electrophoresis using a NucleoSpin Extract II Kit (Clontech
Laboratories, Inc., Mountain View, CA, USA). Purified PCR amplicons were cloned using the pGEM-T Easy vector system (Promega, Fitchburg, WI, USA). About 10 positive clones from each sample (70 total) were selected at random for DNA sequencing, which was carried out at BGI (Shenzhen, China). Sequences for amoA genes were binned into operational taxonomic units (OTUs) exhibiting 95\% nucleotide sequence identity using MOTHUR (Schloss et al. 2009). Cloned sequences of the amoA gene for ammonia-oxidizing bacterial and archaeal genes were identified by searching against DNA sequences archived in GenBank using the NCBI Basic Alignment and Search Tool (http://blast.ncbi.nlm.nih.gov/Blast.cgi).

We conducted phylogenetic cluster analysis using the unweighted pair group method with arithmetic averaging algorithm to estimate $\beta$-diversity and to visualize microbial community diversity (Lozupone and Knight 2005). Neighbor-joining trees were constructed using Molecular Evolutionary Genetics Analysis v. 5.0 (Tamura et al. 2011). In an attempt to root the AOA tree, we included the amoA sequences of Nitrosarcheum sp. (GenBank Accession Numbers LN823900.1 and LN823940) in our analysis.

\section{Archiving of new amoA sequences}

New $a m o A$ sequences have been deposited in GenBank under Accession Numbers MF959625 to MF959695.

\section{Results \\ Water quality}

Quality parameters for treated water returned to the rearing tanks (Table 2) were all appropriate for the production of grouper (Yang et al. 2016). Mean temperature was $23.3 \pm 0.8{ }^{\circ} \mathrm{C}$, suitable for grow-out of hybrid grouper. Through the course of production, the mean dissolved oxygen concentration was $7.2 \pm 0.3 \mathrm{mg} / \mathrm{l}$, which is close to saturation at $23^{\circ} \mathrm{C}$. Since nitrification was well established in the series of biofilters before culture commenced, neither total ammonia nitrogen (TAN) nor nitrite accumulated during fish production. The mean TAN concentration entering each tank was $0.219 \pm 0.012 \mathrm{mg} / \mathrm{l}$, nitrite $0.022 \pm 0.002 \mathrm{mg} / \mathrm{l}$, and chemical oxygen demand $0.96 \pm 0.06 \mathrm{mg} / \mathrm{l}$. These results show that this series of biofilters metabolized ammonia

Table 1 Technical details for microbial community characterization

\begin{tabular}{|c|c|c|c|}
\hline Primers & Target taxa & PCR conditions & References \\
\hline $\begin{array}{l}\text { Arch-amoAF } \\
\text { Arch-amoAR }\end{array}$ & $\mathrm{AOA}$ & $\begin{array}{l}94^{\circ} \mathrm{C} \text { for } 2 \text { min; followed by } 30-35 \text { cycles for } 30 \text { s at } 94^{\circ} \mathrm{C}, 45 \mathrm{~s} \text { at } 53^{\circ} \mathrm{C} \text {, and } 45 \mathrm{~s} \text { at } 72{ }^{\circ} \mathrm{C} \text {, fol- } \\
\text { lowed by } 10 \text { min of final extension at } 72^{\circ} \mathrm{C}\end{array}$ & Francis et al. (2005) \\
\hline $\begin{array}{l}a m o A-1 F \\
a m o A-2 R\end{array}$ & $\mathrm{AOB}$ & $\begin{array}{l}94^{\circ} \mathrm{C} \text { for } 2 \text { min; followed by } 30-35 \text { cycles of } 30 \mathrm{~s} \text { at } 94^{\circ} \mathrm{C}, 45 \mathrm{~s} \text { at } 55^{\circ} \mathrm{C} \text {, and } 45 \mathrm{~s} \text { at } 72^{\circ} \mathrm{C} \text {, followed } \\
\text { by } 10 \text { min of final extension at } 72^{\circ} \mathrm{C}\end{array}$ & Rotthauwe et al. (1997) \\
\hline
\end{tabular}

$A O A$ ammonia-oxidizing archaea, $A O B$ ammonia-oxidizing bacteria 


\begin{tabular}{ll}
$\begin{array}{l}\text { Table } 2 \text { Production and } \\
\text { within the recirculating aquaculture system }\end{array}$ & parameters \\
\hline Final fish density $\left(\mathrm{kg} / \mathrm{m}^{3}\right)$ & 52.3 \\
Fish survival rate & $94 \%$ \\
Feed conversion ratio & 1.2 \\
Specific growth rate $(\% / \mathrm{days})$ & 1.01 \\
Total ammonia nitrogen $(\mathrm{mg} / \mathrm{l})$ & $0.219 \pm 0.012$ \\
Chem. oxygen demand $(\mathrm{mg} / \mathrm{l})$ & $0.96 \pm 0.06$ \\
Nitrite $(\mathrm{mg} / \mathrm{l})$ & $0.022 \pm 0.002$ \\
Dissolved oxygen $(\mathrm{mg} / \mathrm{l})$ & $7.2 \pm 0.3$ \\
pH & $7.8 \pm 0.2$ \\
Temperature $\left({ }^{\circ} \mathrm{C}\right)$ & $23.3 \pm 0.8$ \\
\hline
\end{tabular}

effectively, providing a suitable context for considering the conditions under which ammonia-oxidizing bacteria and archaea functioned.

\section{Fish growth and production}

Growth performance of the hybrid grouper (Epinephelus lanceolatus ${ }^{\top} \times$ E. fuscoguttatus ) through the 240day on-growing period met expectations for commercial production (Table 2). Starting at $156.3 \pm 11.8 \mathrm{~g}$, the grouper grew quickly to $1324 \pm 53.6$ g. From a low starting density of $6.08 \mathrm{~kg} / \mathrm{m}^{3}$, final densities reached as high as $52.3 \mathrm{~kg} / \mathrm{m}^{3}$. No disease outbreaks occurred, and no chemotherapeutics or antibiotics were used during the production period. Survival through the culture period was around 94\%. Through the entire production period, the specific daily growth rate was $0.89 \%$ body weight/ day and the feed conversion ratio was 1.2. Production of hybrid grouper in the recirculating system exhibited higher density, survival rate and feed conversion than in flow-through and intensive pond systems (Wang et al. 2004; Li et al. 2013), indicating high performance of the biofilter and recirculating system.

\section{Ammonia-oxidizing bacteria}

Following amplification of the bacterial amo $A$ gene, 46 clones were randomly selected for DNA sequencing, and 31 unique bacterial $a m o A$ gene sequences were observed. Phylogenetic analysis (Fig. 2) showed that most represented operational taxonomic units (OTUs) within the genus Nitrosomonas within the $\beta$-Proteobacteria. This included eight strains of Nitrosomonas marina, two $N$. aestuari, one $N$. chryotolerans, one $N$. stercornis, three Nitrosomonas europaea, one $N$. ureae, and one $N$. eutropha. The sequences for N. europaea [AF058691] and ATCC[JN099309] clustered separately from that for $N$. europaea ATCC19718[AL954747]. That DNA sequences of $N$. europaea are arrayed on both sides of the principal node of the phylogram is likely the consequence of there being two differentiated copies of $a m o A$ in its genome (Sinigalliano et al. 1995). Not all OTUs were associated with described species, an outcome not unusual in DNA metabarcoding studies (Purkhold et al. 2003; Tang et al. 2014). We observed 11 distinct amo $A$ sequences from different strains of Nitrosomonas that could not be associated with a described species. Our results also included four unidentified OTUs that could not be related to a known species, but because of their high similarity with other Nitrosomonas sequences, seem likely to represent lineages within the genus.

\section{Ammonia-oxidizing archaea}

From the library for archaeal amo $A$ genes, 24 randomly drawn clones were sequenced. Phylogenetic analysis of the 18 unique archaeal $a m o A$ gene sequences (Fig. 3) showed that they clustered into seven OTUs, and that most of the sequences were homologous to those of Nitrosopumilus species. We detected the presence of two different strains of Nitrosopumilus maritimus (SCM1 and NAOA6), a common archaeon in seawater; the species having first been isolated from sediment in a marine aquarium (Konneke et al. 2005), its detection in a marine RAS is not surprising. We observed one amo $A$ sequence each for $N$. koreensis strain AR1, N. piranensis strain D3C, and $N$. adriaticus strain NF5, as well as five strains for unnamed member(s) of the genus, denoted Nitrosopumilis sp. AR2, SW, HCA1, NM25, and PS0 in Fig. 3. Our results also include six $a m o A$ sequences from unidentified archaean OTUs; as noted above, inability to associate environmental DNA sequences with known taxa is not surprising, as metagenomics studies often uncover unknown taxa; this issue is particularly the case for archaea, for which our understanding is still emerging. That DNA sequences for the nominal outgroup, the confamilial Nitrosarcheum sp. was grouped within the lower branch for Nitrosopumilus species was unexpected, and can be explained by: (1) too little sequence having been analyzed to resolve true phylogenetic relationships, or (2) improperly resolved taxonomy having been incorporated into the archived database.

\section{Discussion}

We characterized the ammonia-oxidizing microbial community of biofilters in a marine recirculating aquaculture system producing hybrid grouper. DNA barcoding using the amo $A$ gene showed the AOB community to be dominated by numerous Nitrosomonas species and strains and the AOA community by Nitrosopumilus species and strains. Our results contrast somewhat with those of earlier studies, at least in part because of methodological advances. Hovanec and DeLong (1996) used the rRNAbased metabarcoding approach and the limited DNA 


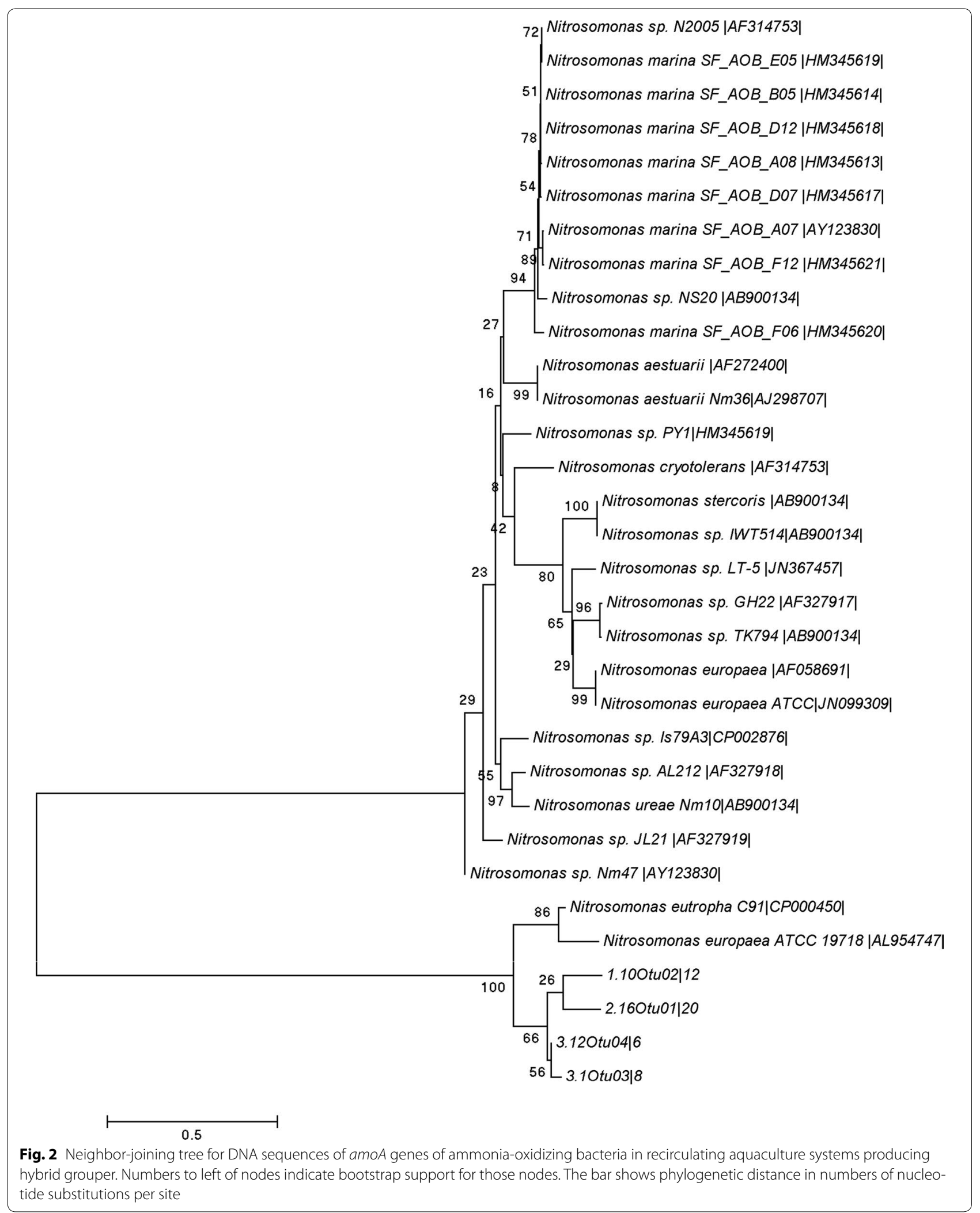




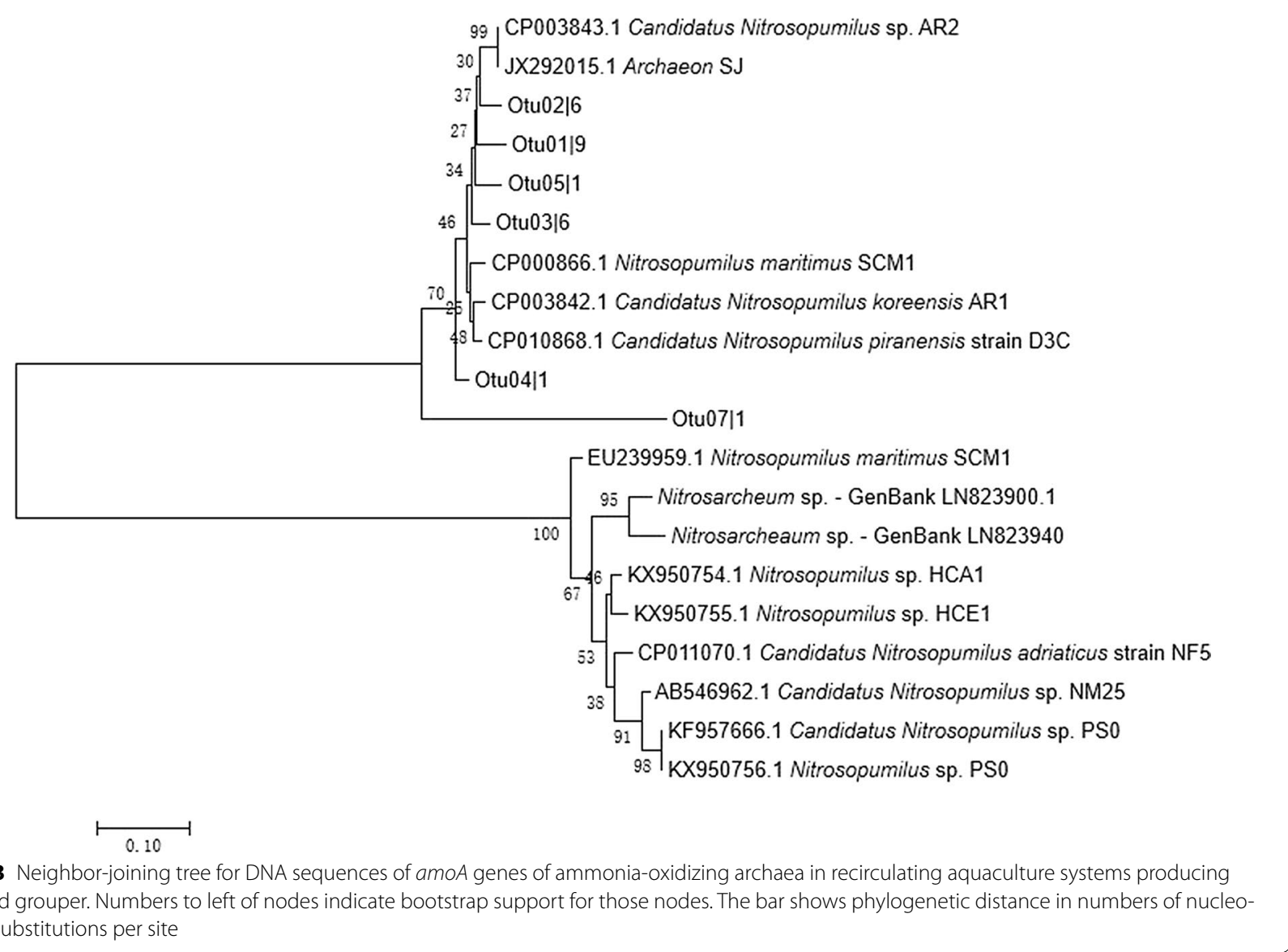

sequence archives of the time, the latter limiting their ability to identify ammonia-oxidizing species in freshwater and saltwater aquaria. Hence, they were limited to reporting that nitrifiers appeared to be dominated by Nitrosomonas europaea and its close relatives, while we are able to report 28 species and strains of Nitrosomonas. Using denaturing gradient gel electrophoresis (DGGE) and $16 S$ rRNA sequencing, Tal et al. (2003) detected $N$. cryotolerans and Nitrospira marina, as well as heterotrophs (including Pseudomonas sp., Sphingomonas sp., and Planctomyces sp., suggesting the possibility of anaerobic ammonia oxidation) in a system producing gilthead sea bream (Sparus auratus). Using a clone library of partial $16 S$ rRNA gene sequences to characterize the biofilter microbial communities in a marine RAS producing pufferfish Takifugu rubripes, Itoi et al. (2006) showed $N$. aestuarii, Nitrosomonas sp. Nm143, and two clones forming a separate cluster. Using fluorescent in situ hybridization, Foesel et al. (2008) reported that the most abundant AOB in trickling filters for marine RAS producing gilthead seabream were Nitrosomonas sp. Nm143 and N. marina. In a review of published studies, Schreier et al. (2010) reported Nitrosomonas cinnybus/nitrosa and
Nitrosococcus mobilis in the biofilters of marine RAS. Lee et al. (2016) performed sequencing of $16 \mathrm{~S}$ rRNA amplicons of $\mathrm{AOB}$ in a recirculating aquaculture system producing sevenband grouper (Epinephelus fasciatus) at three temperatures and three salinities. Their results included five Nitrospira taxa, four Nitrosomonas, two Nitrospina, and many unassigned OTUs. Interestingly, the $\mathrm{AOB}$ communities they characterized were rather different from ours, even though this being a recent publication, the DNA sequence archive that they used was similarly elaborated. These differences among these communities may be a real consequence of salinity and temperature differences, or may be a consequence of use of $16 \mathrm{~S}$ rRNA versus $a m o A$ barcoding approaches. Characterizing marker lipids and screening $16 S$ rRNA genes, Kruse et al. (2013) showed that the AOB in moving-bed biofilters of brackish recirculation aquaculture systems producing Pacific white shrimp (Penaeus vannemei) and barramundi (Lates calcarifer) included four different phylogenetic clusters within the marine sublineage IV of Nitrospira. 16S rRNA barcoding of bacterial communities of biofilters in an RAS producing tongue sole (Cynoglossus semilaevis) (Ruan et al. 2015) suggested that the 
AOB belonged to Nitrosomonas clusters; while this result was similar to ours, we were able to show a greater diversity of known and unknown members of the genus. In two RAS producing seabass (Dicentrarchus labrax), $16 \mathrm{~S}$ rRNA barcoding (Keuter et al. 2017) showed that AOB belonged almost exclusively to Nitrosomonas, of which dominant species shifted in both systems over time.

Use of amoA metabarcoding and phylogenetic analysis allows greater ability to detect and characterize ammonia-oxidizing microbes, although the state of development of the DNA sequence archive at any point in time constrains the ability to relate amplification products to particular species. Our results builds upon earlier work by making use of better-developed DNA sequence archives and association of more clones with particular species, whose environmental requirements are now better known, as discussed below. Thus, we were able to go farther than Urakawa et al. (2008), many of whose clones could not be associated with species and strain. They identified 5-15 ammonia-oxidizing bacterial species per recirculating aquaculture system, while we identified 31. We observed more species of Nitrosomonas, including many strains of $N$. marina. We did not see Nitrospira or Nitrosococcus species. Urakawa et al. (2008) could characterize clones in Cluster "A" in their archaeal phylogram only as clones related to $N$. maritimus, and the other four clusters only by their derivation from particular RAS or from particular ecosystems, without associated species names. Sauder et al. (2011) used rtPCR to look at $a m o A$ and $16 S$ rRNA genes of nitrifiers in the biofilters of freshwater and saltwater hobby-scale aquaria, i.e., smaller systems with lesser waste loadings than commercial aquaculture RAS. Saltwater system biofilters showed both $\mathrm{AOB}$ and $\mathrm{AOA}$, the latter dominating in five of eight systems, and the authors suggested that both communities contribute substantially to nitrification. The 84 archaeal amoA clones included Candidatus N. maritimus and Candidatus Cenarchaeum symbiosum A. Sakami et al. (2012) assayed $a m o A$ DNA sequences in three biofilters for marine RAS producing unspecified fish under various environmental conditions. Among the AOBs were 19 OTUs, most not affiliated with a species. Those identified included four Nitrospira, four Nitrosomonas, and one Nitrosococcus species or strains. In contrast, the AOBs in the RAS system that we characterized were dominated by a wider range of Nitrosomonas species and strains. Among 240 archaeal $a m o A$ sequences examined by Sakami et al. (2012) were 63 distinct clones. Most were not identified to species, $N$. maritimus being the only one identified. Our results showed two strains of that species, three named and five unnamed congeners, and six archaeal OTUs of unknown affiliation. Analyzing the biofilter nitrifier community in a marine RAS producing unspecified shrimp, Brown et al. (2013) examined $\mathrm{AOB}$ populations by targeting $16 S \mathrm{rRNA}$ and AOA by using amo $A$ genes. Archaeal $a m o A$ genes were more abundant in all compartments of the RAS than bacterial amo $A$ genes. In results similar to ours, most AOB were related to Nitrosomonas marina and most AOA to $N$. maritimus. Using DGGE to characterize thaumarchaeal $16 S$ rRNA genes, Bagchi et al. (2014) also showed low AOA diversity. Thus, there are considerable differences among studies, even those using similar methods. These differences may be attributable to the environmental conditions (see following sections), systems operations conditions (Bartelme et al. 2017), or source of seeding (Gross et al. 2003).

Environmental factors, such as $\mathrm{pH}$, oxygen concentration and temperature, will affect the compositions of microbial communities responsible for nitrification. Both $\mathrm{AOB}$ and $\mathrm{AOA}$ are sensitive to a number of environmental conditions (reviewed by You et al. 2009); the dynamics of nitrifying organisms in response to nutrient removal and water quality remains poorly understood. Hence, it is necessary to explore and better understand how $\mathrm{AOB}$ and $\mathrm{AOA}$ respond to environmental perturbations and affect water quality in a diversity of aquaculture systems.

\section{Ammonia oxidizing bacterial community composition}

Ammonia-oxidizing bacteria are distinguished on the basis of DNA homology, GC content of DNA, cellular shape and ultrastructure, as well as characters relevant to environmental adaptation, such salt requirement, ammonia tolerance, ability to utilize urea, and wholecell proteomics (Koops et al. 1991). Using a metagenomics approach, we characterized the $\mathrm{AOB}$ community on the biofilters of a marine aquaculture facility producing hybrid grouper and uncovered a diversity of both described and undescribed species. Those for which environmental adaptations are known exhibited contrasting environmental optima. We observed three amo $A$ gene sequences with high homology to three different strains of $N$. europaea, a microbe first isolated from soil and common in soil, freshwater, and sewage, with no requirement for salt (Koops et al. 1991). N. europaea needs high concentrations of ammonia for energy to grow and divide, and hence grows slowly; it tolerates a $\mathrm{pH}$ of 6.0-9.0, with slightly basic conditions being optimal; it has aerobic metabolism, and prefers temperatures between 20 and $30{ }^{\circ} \mathrm{C}$ (Chain et al. 2003). We observed one amoA sequence from $N$. stercoris, which occurs in strongly eutrophic environments such as wastewater treatment plants; that they grow at $1000 \mathrm{mM}$ ammonium suggests that these ammonia oxidizers contribute to removing high concentrations of ammonia under highly eutrophic conditions (Nakagawa and Takahashi 
2015). One amoA sequence was from $N$. cryotolerans, a cold-tolerant obligate halophilic bacterium first isolated from Alaskan marine waters (Jones et al. 1988). We had one observation of $N$. eutropha, a bacterium found in highly eutrophic environments such as sewage disposal systems; it tolerates elevated ammonia concentrations, can grow anaerobically, and uses nitrite as an electron acceptor and hydrogen as a reductant. We observed two amo $A$ sequences from $N$. aestuarii, which is common in marine and estuarine waters and requires salt, with optimum growth around 17.5 ppt $\mathrm{NaCl}$ (Koops et al. 1991). We observed eight distinct amo $A$ sequences from different strains of $N$. marina, which occurs in marine waters and salt lakes; it requires salt and exhibits optimum growth at around 20 ppt $\mathrm{NaCl}$ (Koops et al. 1991).Observation of a diverse assemblage of Nitrosomonas and perhaps other ammonia-oxidizing bacteria with differing optimal ammonia and salinity concentrations, as well as differing requirements for oxygen and electron receptors, suggests that ammonia oxidation can go forward under a range of environmental conditions. This diversity also suggests that ammonia will be oxidized effectively in different microhabitats within biofilms throughout the treatment train. These inferences suggest how the process of ammonia oxidation proved resilient in the face of changing environmental conditions through time for fish production within the RAS that we characterized, especially regarding heightened ammonia loadings as fish density increased through the production cycle.

\section{Ammonia oxidizing archaeal community composition}

Growing understanding of physiological differences among AOA suggests adaptive differentiation, which may support niche partitioning in the natural environment. Ergruder et al. (2009) outlined the possible niches of AOA, and proposed that the AOA might be important actors within the nitrogen cycle in low-nutrient, low-pH, and sulfide-containing environments. We suggest the possibility of niche partitioning within aquaculture biofilters, which in turn suggests heightened biofilter function and resiliency, as follows. The majority of AOA in marine ecosystems belong to Group 1.1a or Marine Group I within the candidate order Nitrosopumilales (Stieglmeier et al. 2014), which includes N. maritimus SCM1 (Konneke et al. 2005). Archaea closely related to N. maritimus SCM1 subsequently were isolated from marine and estuarine sediments (Mosier et al. 2012; Park et al. 2014) and coastal waters (Qin et al. 2014). Although all representatives of Group 1.1a couple ammonia oxidation with autotrophic carbon fixation, they vary in metabolic traits including the ability to utilize urea and dependence on small amounts of organic compounds (Park et al. 2014; Qin et al. 2014). Archaea of genus Nitosopumilis can use ammonia as an energy source and perform carbon fixation through the 3-hydroxypropionate/4-hydroxybutyrate pathway (Berg et al. 2007). Physiological and genomic data show that each strain has different metabolic and functional traits that may reflect contrasting modes of life (Bayer et al. 2016). Gene sequences similar to those of $N$. maritimus have been PCR-amplified from pelagic ocean waters (Karner et al. 2001; Wuchter et al. 2006) and a wastewater treatment plant (Park et al. 2006). N. koreensis was first isolated from sediment collected from the Arctic Ocean (Park et al. 2010). Genes for multicopper oxidase and blue copper domain-containing proteins that are potentially involved in energy conservation through ammonia oxidation were less enriched in the genome of $N$. koreensis strain AR1 than in other members of the genus (Park et al. 2012). Absence of a hydroxylamine oxidoreductase gene in strain AR1 indicated a novel ammonia oxidation pathway. While the genome contained genes for the 3-hydroxypropionate/4hydroxybutyrate pathway of carbon fixation, the high frequency $(\sim 30 \%)$ of unique genes in strain AR1 suggested the potential for niche differentiation among sediment-dwelling AOA. For example, The AR1 genome lacked a high-affinity phosphate-uptake operon found in the genome of N. maritimus. Candidatus N. piranensis strain D3C and Candidatus $N$. adriaticus strain NF5 were obtained from the same location and are closely related phylogenetically, but appeared to exhibit different metabolic traits and functional adaptations (Bayer et al. 2016). N. piranensis D3C is non-motile, shows versatility in substrate utilization, and can use urea as an alternative substrate to ammonia. It has a second, divergent copy of the $A m o B$ subunit of ammonia monooxygenase, which suggests additional catalytic function and greater metabolic versatility. $N$. adriaticus NF5 contains many chemotaxis-related genes, can express archaella (whiplike structures for motility), and may sense and actively seek favorable microenvironments such as nutrient-rich particles (Bayer et al. 2016). Factors influencing the diversity of AOA in biofiltration systems remain unknown and largely unexplored; Urakawa et al. (2008) suggested that salinity, ammonium concentration, $\mathrm{pH}$, and temperature may be the most important factors. We hypothesize that contrasting environmental optima among Nitrosopumilus species and archaea generally might contribute to their coexistence in biofilters, and that the presence of a consortium of such species may contribute to heightened nitrification and functional resiliency. This hypothesis might be tested by collecting and characterizing biofilm from different points in the treatment train and through the production cycle as ammonia loading increases. 


\section{Are ammonia-oxidizing archaea important in marine aquaculture biofilters?}

Ammonia oxidation long was thought to be performed mainly by certain lineages of $\beta$ - and $\gamma$-Proteobacteria (Purkhold et al. 2000). However, the discovery of ammonia-oxidizing archaea (Konneke et al. 2005; Treusch et al. 2005) changed perception of microbial nitrification and nitrogen cycling and led to questions regarding nitrifier diversity, the contribution of archaea, and the ecology and evolutionary origins of ammonia oxidation-based metabolism. The Crenarchaeota taxon to which Notrosopumilis belongs is estimated to comprise $20-30 \%$ of ocean picoplankton (Karner et al. 2001). Metagenomic and biomarker data have shown nitrification by Group 1 Crenarchaeota in a variety of mesophilic aerobic environments. In the North Sea, the ammonia oxidation rate corresponded to numbers of cells and amoA copies of Crenarchaea species exhibiting close sequence identity to $N$. maritimus, while bacterial $a m o A$ copies remained 1-2 orders of magnitude less common (Wuchter et al. 2006). While per-cell rates of ammonia oxidation are less for AOA $\left(2-4 \times 10-15 \mathrm{~mol} \mathrm{NH}_{3}\right.$ /cell/day, Wuchter et al. 2006) than for AOB $\left(6-20 \times 10-15 \mathrm{~mol} \mathrm{NH}_{3} /\right.$ cell/day, Ward 1987), observation of 1000-3000-times greater abundance of AOA than AOB in marine environments (Karner et al. 2001; Wuchter et al. 2006) suggested that archaea may be the more important nitrifiers. The ammonia affinity and oxidation kinetics exhibited by $N$. maritimus strain SCM1 under oligotrophic conditions adapts it to life under conditions of nutrient limitation (Martens-Habbena et al. 2009); the threshold concentration needed for growth of strain SCM1 could be as low as 10-20 nM ammonium, which suggests that Nitrosopumilus-like AOA could compete successfully for nitrogen with heterotrophic bacterioplankton and phytoplankton.

Using PCR primers targeting archaeal amoA, Francis et al. (2005) found AOA to be pervasive in areas of the ocean that are critical for the global nitrogen cycle, including the base of the euphotic zone, suboxic water columns, and estuarine and coastal sediments. Diverse and distinct AOA communities were associated with each of these habitats, with little overlap between water columns and sediments. Within marine sediments, most AOA sequences are unique to individual sampling locations, whereas a small number of sequences are evidently cosmopolitan in distribution. Considering the abundance of non-extremophilic archaea in the ocean, their results suggest that AOA may play a significant, but previously unrecognized, role in the global nitrogen cycle. Walker et al. (2010) reported the 1,645,259-bp genome of Candidatus $N$. maritimus strain SCM1, revealing highly copper-dependent systems for ammonia oxidation and electron transport that are distinctly different from known ammonia-oxidizing bacteria. The conservation of $N$. maritimus genome organization and gene content among marine metagenomes indicates that the unique physiology of these ammonia-oxidizing archaea may play a significant role in the nitrogen cycle. The contribution of AOA to nitrification in RAS biofilters, however, is yet unresolved. Given the high affinity of Nitrosopumilus-like AOA and its reaction kinetics, the reasonably high diversities of AOA that we and Urakawa et al. (2008) observed would suggest considerable ammonium flux through this component of the biofilm community. However, the low abundance of Crenarchaeotan archaea in a trickling filter biofilm observed by Foesel et al. (2008) using fluorescent in situ hybridization led them to assess their contribution to overall nitrification to be negligible. RAS biofilters host complex microbial communities with multiple ammonia oxidation pathways and whose composition is affected by system operations (Bartelme et al. 2017). Examining the temporal and spatial stability of $\mathrm{AOB}$ and AOA in biofilters, Bagchi et al. (2014) used qPCR to quantify amo $A$ gene abundance and showed that in marine systems, AOB outnumbered AOA by three to five orders of magnitude. Using $16 S$ rRNA and $a m o A$ barcoding, Bartelme et al. (2017) showed that Nitrosomonas was present at all water depths and sampling times, but their abundance was three orders of magnitude less than that for AOA and varied over time.

That our results differed in some regards from those of some other studies supports the view that $A O B$ and AOA communities vary widely with culture and environmental conditions, particularly substrate availability, and perhaps also with the environmental conditions under which the culture water was taken (Sakami et al. 2012). The relative abundance of AOB and AOA and their contributions to nitrification may vary with environmental conditions, in particular, with substrate availability. Under ammonia-limited conditions, organisms with Nitrosopumilus-like kinetics may outcompete AOB and dominate nitrification, while AOB may be more competitive in environments higher nutrient levels. Organic matter-rich particles may provide niches for nitrifiers with significantly different kinetic properties (Karl et al. 1984; Phillips et al. 1999; Martens-Habbena et al. 2009), such as different members of the Nitrosomonas eutropha lineage (Phillips et al. 1999). We note that organic-rich particles are abundant in RAS, and their presence may affect the rate of nitrification and the microbial subcommunity responsible for it. Brown et al. (2013) noted that water quality and biofilm attachment media played a role in the competitiveness of AOA over AOB and among different species of Nitrospira. Using qPCR, Sauder et al. (2011) detected both thaumarchaeal and bacterial amo $A$ genes in all saltwater samples they examined, with AOA 
genes outnumbering $\mathrm{AOB}$ genes in five of eight biofilters. The compositions of ammonia-oxidizing communities in freshwater and marine systems were distinct, and composite clone libraries of AOA amoA genes revealed distinct freshwater and saltwater clusters. Sequencing $16 \mathrm{~S}$ rRNA amplicons, Gonzalez-Silva et al. (2016) showed significantly different $\mathrm{AOB}$ communities in cultures originating from freshwater, brackish $(20 \%)$ and seawater environments; $60 \%$ of the total operational taxonomic units (OTUs) in the ammonia-oxidizing bacteria (AOB) were unique to that environment. Real-time PCR would provide an assessment of the level of $a m o A$ gene expression, while assessment of ammonia flux (Ward 1987; Wuchter et al. 2006) would provide the direct measure of greatest interest. More thorough understanding of the ammonia-oxidizing community may promote more targeted seeding to initiate nitrification in RAS biofiters (Gross et al. 2003) and to support management of biofilters through the production cycle.

\begin{abstract}
Abbreviations
amoA: ammonia monooxygenase gene; $\mathrm{AOA}$ : ammonia-oxidizing archaea; AOB: ammonia-oxidizing bacteria; COD: chemical oxygen demand; DGGE: denaturing gradient gel electrophoresis; FCR: feed conversion ratio; NOB: nitrite-oxidizing bacteria; OTU: operational taxonomic unit; PCR: polymerase chain reaction; RAS: recirculating aquaculture system; TAN: total ammonia nitrogen; UV: ultraviolet; $16 S$ rRNA: 16 S ribosomal RNA gene.
\end{abstract}

\section{Authors' contributions}

$\mathrm{ZH}, \mathrm{YL}$, and $T M$ conceived the study. JZ and WL raised the fish and operated the recirculating aquaculture system. ZH and XS prepared materials for submission for DNA sequencing. DD and LP performed data analysis. ZH and $\mathrm{EH}$ wrote the manuscript. All authors read and approved the final manuscript.

\section{Author details}

${ }^{1}$ Department of Fisheries, Ocean University of China, Qingdao 266003, People's Republic of China. ${ }^{2}$ Department of Fish and Wildlife Conservation, Virginia Polytechnic Institute and State University, Blacksburg, VA 24061, USA. ${ }^{3}$ Rizhao Aquaculture Technology Extension Station, Rizhao 226600, People's Republic of China. ${ }^{4}$ Laizhou Mingbo Aquatic Co., Ltd., Lai Zhou 261418, People's Republic of China.

\section{Acknowledgements}

The participation of EMH in this project was supported in part by the Virginia Agricultural Experiment Station under the U.S. Department of Agriculture Hatch Program. We are grateful for the constructive comments received in peer review of the manuscript.

\section{Competing interests}

The authors declare that they have no competing interests.

\section{Availability of data and materials}

All data will be posted online in the advent of acceptance of the manuscript for publication by the journal.

\section{Consent for publication}

All authors have seen and consented to submission of this manuscript in its current form.

\section{Ethics approval and consent to participate}

This study did not involve human participants. Fish were produced under conditions of routine commercial practice.

\section{Funding}

This study was supported by the National Natural Science Foundation of China (31502212).

\section{Publisher's Note}

Springer Nature remains neutral with regard to jurisdictional claims in published maps and institutional affiliations.

Received: 11 January 2018 Accepted: 5 February 2018

Published online: 10 February 2018

\section{References}

APHA (American Public Health Association), American Water Works Association, Water Environment Federation (1995) Standard methods for the examination of water and wastewater, 19th edn. APHA, Washington, DC

Bagchi S, Vlaeminck SE, Sauder LA, Mosquera M, Neufeld JD, Boon N (2014) Temporal and spatial stability of ammonia-oxidizing archaea and bacteria in aquarium biofilters. PLoS ONE 9(12):e113515. https://doi.org/10.1371/ journal.pone.0113515

Bartelme RP, McLellan SL, Newton RJ (2017) Freshwater recirculating aquaculture system operations drive biofilter bacterial community shifts around a stable nitrifying consortium of ammonia-oxidizing Archaea and comammox Nitrospira. Front Microbiol 8:101. https://doi.org/10.3389/ fmicb.2017.00101

Bayer B, Vojvoda J, Offre P, Alves RJE, Elisabeth NH, Garcia JAL, Volland JM, Srivastava A, Schleper C, Herndl GJ (2016) Physiological and genomic characterization of two novel marine thaumarchaeal strains indicates niche differentiation. Int Soc Microb Ecol J 10:1051-1063. https://doi. org/10.1038/ismej.2015.200

Berg IA, Kockelkorn D, Buckel W, Fuchs G (2007) A 3-hydroxypropionate/4hydroxybutyrate autotrophic carbon dioxide assimilation pathway in Archaea. Science 318:1782-1786. https://doi.org/10.1126/ science. 1149976

Bergmann DJ, Hooper AB (1994) Sequence of the gene $a m o B$, for the 43-kDa polypeptide of ammonia monooxygenase of Nitrosomonas europaea. Biochem Biophys Res Commun 204:759-762. https://doi.org/10.1006/ bbrc. 1994.2524

Blancheton JP, Attramadal KLK, Michaud L, Roque d'Orbcastel E, Vadsteain O (2013) Insight into bacterial population in aquaculture systems and its implication. Aquacult Eng 53:30-39. https://doi.org/10.1016/j. aquaeng.2012.11.009

Bock E, Koops HP, Harms H (1986) Cell biology of nitrifying bacteria. In: Prosser $\mathrm{Jl}$ (ed) Nitrification. Special publication of the Society for General Microbiology, vol 20. IRL Press, Oxford

Brown MN, Briones A, Diana J, Raskin L (2013) Ammonia-oxidizing archaea and nitrite-oxidizing Nitrospiras in the biofilter of a shrimp recirculating aquaculture system. FEMS Microbiol Ecol 83:17-25. https://doi. org/10.1111/j.1574-6941.2012.01448.x

Ch'ng CL, Senoo S (2008) Egg and larval development of a new hybrid grouper, tiger grouper Epinephelus fuscoguttatus $\times$ giant grouper $E$. lanceolatus. Aquacult Sci (Japan) 56:505-512. https://doi.org/10.11233/ aquaculturesci.56.505

Chain P, Lamerdin J, Larimer F, Regala W, Lao V, Land M, Hauser L, Hooper A, Klotz M, Norton J, Sayavedra-Soto L (2003) Complete genome sequence of the ammonia-oxidizing bacterium and obligate chemolithoautotroph Nitrosomonas europaea. J Bacteriol 185:2759-2773. https://doi. org/10.1128/JB.185.9.2759-2773.2003

Erguder TH, Boon N, Wittebolle L, Marzorati M, Verstraete W (2009) Environmental factors shaping the ecological niches of ammonia-oxidizing archaea. FEMS Microbiol Rev 33:855-869

Fishery Bureau, Ministry of Agriculture, China (2015) China Fishery Statistics Yearbook 2015. China Agricultural Press, Beijing. ISBN: 97887109205543

Foesel BU, Gieseke A, Schwermer C, Stief P, Koch L, Cytryn E, de la Torre JR, van Rijn J, Minz D, Drake HL (2008) Nitrosomonas Nm143-like ammonia oxidizers and Nitrospira marina-like nitrite oxidizers dominate the nitrifier community in a marine aquaculture biofilm. FEMS Microbiol Ecol 63:192-204. https://doi.org/10.1111/j.1574-6941.2007.00418.x 
Francis CA, Roberts KJ, Beman JM, Santoro AE, Oakley BB (2005) Ubiquity and diversity of ammonia-oxidizing archaea in water columns and sediments of the ocean. Proc Natl Acad Sci USA 102:14683-14688. https://doi. org/10.1073/pnas.0506625102

Gonzalez-Silva BM, Jonassen KR, Bakke I, Østgaard K, Vadstein O (2016) Nitrification at different salinities: Biofilm community composition and physiological plasticity. Water Res 15:48-58

Gross A, Nemirovsky A, Zilberg D, Khaimov A, Brenner A, Snir E, Ronen Z, Nejidat A (2003) Soil nitrifying enrichments as biofilter starters in intensive recirculating saline water aquaculture. Aquaculture 223:51-62

Hooper AB (1989) Biochemistry of the nitrifying lithoautotrophic bacteria. In: Schlegel HG, Bowien B (eds) autotrophic bacteria. Science Tech Publishers, Madison

Hovanec TA, DeLong EF (1996) Comparative analysis of nitrifying bacteria associated with freshwater and marine aquaria. Appl Environ Microbiol 62:2888-2896

Huang Z, Wan R, Song X, Liu Y, Hallerman E, Dong D, Zhai J, Zhang H, Sun L (2016) Metagenomic analysis shows diverse, distinct bacterial communities in biofilters among different marine recirculating aquaculture systems. Aquacult Int 24:1393-1408. https://doi.org/10.1007/ s10499-016-9997-9

Itoi S, Niki A, Sugita H (2006) Changes in microbial communities associated with the conditioning of filter material in recirculating aquaculture systems of the pufferfish Takifugu rubripes. Aquaculture 56:287-295

Jones RD, Morita RY, Koops HP, Watson SW (1988) A new marine ammoniumoxidizing bacterium, Nitrosomonas cryotolerans sp. nov. Can J Microbiol 34:1122-1128. https://doi.org/10.1139/m88-198

Karl DM, Knauer GA, Martin JH, Ward BB (1984) Bacterial chemolithotrophy in the ocean is associated with sinking particles. Nature 309:54-56

Karner MB, DeLong EF, Karl DM (2001) Archaeal dominance in the mesopelagic zone of the Pacific Ocean. Nature 409:507-510. https://doi. org/10.1038/35054051

Keuter S (2011) Characterization of nitrifying bacteria in marine recirculation aquaculture systems with regard to process optimization. Dissertation, University of Hamburg

Keuter S, Beth S, Quantz G, Schultz C, Spieck E (2017) Longterm monitoring of nitrification and nitrifying communities during biofilter activation of two marine recirculation aquaculture systems (RAS). Int J Aquacult Fish Sci 3:51-61

Konneke M, Bernhard AE, de la Torre JR, Walker CB, Waterbury JB, Stahl DA (2005) Isolation of an autotrophic ammonia-oxidizing marine archaeon. Nature 437:543-546

Koops HP, Bottcher B, Moller UC, Pommerening-Roser A, Stehr G (1991) Classification of eight new species of ammonia-oxidizing bacteria: Nitrosomonas communis sp. nov., Nitrosomonas ureae sp. nov., Nitrosomonas aestuarii sp. nov., Nitrosomonas marina sp. nov., Nitrosomonas nitrosa sp. nov., Nitrosomonas eutropha sp. nov., Nitrosomonas oligotropha sp. nov. and Nitrosomonas halophila sp. nov. Microbiology 137:1689-1699

Kruse M, Keuter S, Bakker E, Spieck E, Eggers T, Lipski A (2013) Relevance and diversity of Nitrospira populations in biofilters of brackish RAS. PLOS ONE 5:e64737

Lee DE, Lee J, Kim YM, Myeong J, Kim KH (2016) Uncultured bacterial diversity in a seawater recirculating aquaculture system revealed by 165 rRNA gene amplicon sequencing. J Microbiol 54:296

Li Y, Han W, Peng S (2013) Study on the aquaculture technology of Epinephelus fuscoguttatus $\times$ giant grouper E. lanceolatus in high-level pond system. Sci Aquacult 7:41-42 (in Chinese)

Lozupone C, Knight R (2005) UniFrac: a new phylogenetic method for comparing microbial communities. Appl Environ Microbiol 71:8228-8235. https://doi.org/10.1128/AEM.71.12.8228-8235.2005

Martens-Habbena W, Berube PM, Urakawa H, José R, Stahl DA (2009) Ammonia oxidation kinetics determine niche separation of nitrifying archaea and bacteria. Nature 461:976-979. https://doi.org/10.1038/nature08465

McTavish H, Fuchs JA, Hooper AB (1993) Sequence of the gene coding for ammonia monooxygenase in Nitrosomonas europaea. J Bacteriol 175:2436-2444. https://doi.org/10.1128/jb.175.8.2436-2444.1993

Michaud L, Lo Giudice A, Interdonato F, Triplet S, Liu Y, Blancheton JP (2014) $\mathrm{C} / \mathrm{N}$ ratio-induced structural shift of bacterial communities inside lab-scale aquaculture biofilters. Aquacult Eng 58:77-87. https://doi. org/10.1016/j.aquaeng.2013.11.002
Mosier AC, Lund MB, Francis CA (2012) Ecophysiology of an ammonia-oxidizing archaeon adapted to low-salinity habitats. Micro Ecol 64:955-963. https://doi.org/10.1007/s00248-012-0075-1

Nakagawa T, Takahashi R (2015) Nitrosomonas stercoris sp. nov., a chemautotrophic ammonia-oxidizing bacterium tolerant of high ammonium isolated from composted cattle manure. Microbes Environ 30:221-227. https://doi.org/10.1264/jsme2.ME15072

Park HD, Wells GF, Bae H, Criddle CS, Francis CA (2006) Occurrence of ammonia-oxidizing Archaea in wastewater treatment plant bioreactors. Appl Environ Microbiol 72:5643-5647. https://doi.org/10.1128/AEM.00402-06

Park BJ, Park SJ, Yoon DN, Schouten S, Damsté JS, Rhee SK (2010) Cultivation of autotrophic ammonia-oxidizing archaea from marine sediments in coculture with sulfur-oxidizing bacteria. Appl Environ Microbiol 76:7575-7587. https://doi.org/10.1128/AEM.01478-10

Park SJ, Kim JG, Jung MY, Kim SJ, Cha IT, Kwon KK, Lee JH, Rhee SK (2012) Draft genome sequence of an ammonia-oxidizing archaeon, "Candidatus Nitrosopumilus koreensis" AR1, from marine sediment. J Bacteriol 194:6940-6941. https://doi.org/10.1128/JB.01857-12

Park SJ, Ghai R, Martin-Cuadrado AB, Rodriguez-Valera F, Chung WH, Kwon K, Lee JH, Madsen EL, Rhee SK (2014) Genomes of two new ammoniaoxidizing archaea enriched from deep marine sediments. PLOS ONE 9:e96449. https://doi.org/10.1371/journal.pone.0096449

Phillips CJ, Smith Z, Embley TM, Prosser Jl (1999) Phylogenetic differences between particle-associated and planktonic ammonia-oxidizing bacteria of the $\beta$ subdivision of the class Proteobacteria in the northwestern Mediterranean Sea. Appl Environ Microbiol 65:779-786

Purkhold U, Wagner M, Timmermann G, Pommerening-Röser A, Koops HP (2003) 16 S rRNA and amoA-based phylogeny of 12 novel betaproteobacterial ammonia-oxidizing isolates: extension of the dataset and proposal of a new lineage within the nitrosomonads. Intl J Systemat Evol Microbiol 53:1485-1494. https://doi.org/10.1099/ijs.0.02638-0

Purkhold U, Pommerening-Roser A, Juretschko S, Schmid MC, Koops H-P, Wagner M (2000) Phylogeny of all recognized species of ammonia oxidizers based on comparative 16S rRNA and amoA sequence analysis: implications for molecular diversity surveys. Appl Environ Microbiol 66:5368-5382. https://doi.org/10.1099/ijs.0.02638-0

Qin W, Amin SA, Martens-Habbena W, Walker CB, Urakawa H, Devol AH, Ingalls AE, Moffett JW, Armbrust EV, Stahl DA (2014) Marine ammonia-oxidizing archaeal isolates display obligate mixotrophy and wide ecotypic variation. Proc Natl Acad Sci USA 111:12504-12509. https://doi.org/10.1073/ pnas. 1324115111

Rotthauwe JH, Witzel KP, Liesack W (1997) The ammonia monooxygenase structural gene $a m o A$ as a functional marker: molecular fine-scale analysis of natural ammonia-oxidizing populations. Appl Environ Microbiol 63:4704-4712

Ruan YJ, Guo XS, Ye ZY, Liu Y, Zhu SM (2015) Bacterial community analysis of different sections of a biofilter in a full-scale marine recirculating aquaculture system. N Am J Aquacult 77:318-326

Rurangwa E, Verdegem MCJ (2014) Microorganisms in recirculating aquaculture systems and their management. Rev Aquacult. https://doi. org/10.1111/raq.12057

Sakami T, Andoh T, Morita T, Yamamoto Y (2012) Phylogenetic diversity of ammonia-oxidizing archaea and bacteria in biofilters of recirculating aquaculture systems. Mar Genom 7:27-31

Sauder LA, Engel K, Stearns JC, Masella AP, Pawliszyn R, Neufeld JD (2011) Aquarium nitrification revisited: thaumarchaeota are the dominant ammonia oxidizers in freshwater aquarium biofilters. PLoS ONE 6(8):e23281

Schloss PD, Westcott SL, Ryabin T, Hall JR, Hartmann M, Hollister EB, Lesniewski RA, Oakley BB, Parks DH, Robinson CJ, Sahl JW (2009) Introducing MOTHUR: open-source, platform-independent, community-supported software for describing and comparing microbial communities. Appl Environ Microbiol 75:7537-7541. https://doi.org/10.1128/AEM.01541-09

Schreier HJ, Mirzoyan N, Saito K (2010) Microbial diversity of biological filters in recirculating aquaculture systems. Curr Opin Biotechnol 21:318-325. https://doi.org/10.1016/j.copbio.2010.03.011

Senoo S (2010) Consideration of artificial egg collection technique on fish. IV. Fish culture in Southeast Asia. Aquacult Mag 204:64-67

Sinigalliano CA, Kuhn DN, Jones RD (1995) Amplification of the amoA gene from diverse species of ammonia-oxidizing bacteria and from an 
indigenous bacterial population from seawater. Appl Environ Microbiol 61:1702-2706

Stieglmeier M, Klingl A, Alves RJ, Rittmann SK, Melcher M, Leisch N, Schleper C (2014) Nitrososphaera viennensis gen. nov., sp. nov., an aerobic and mesophilic, ammonia-oxidizing archaeon from soil and a member of the archaeal phylum Thaumarchaeota. Int J Systemat Evol Microbiol 64:2738-2752. https://doi.org/10.1099/ijs.0.063172-0

Sugita H, Nakamura H, Shimada T (2005) Microbial communities associated with filter materials in recirculating aquaculture systems of freshwater fish. Aquaculture 243:403-409. https://doi.org/10.1016/j. aquaculture.2004.09.028

Tal Y, Watts JE, Schreier SB, Sowers KR, Schreier HJ (2003) Characterization of the microbial community and nitrogen transformation processes associated with moving bed bioreactors in closed recirculated mariculture systems. Aquaculture 215:187-202. https://doi.org/10.1016/ S0044-8486(02)00372-1

Tamura K, Peterson D, Peterson N, Stecher G, Nei M, Kumar S (2011) MEGA5: molecular evolutionary genetics analysis using maximum likelihood, evolutionary distance, and maximum parsimony methods. Mol Biol Evol 28:2731-2739. https://doi.org/10.1093/molbev/msr121

Tang Y, Tao P, Tan J, Mu H, Peng L, Yang D, Tong S, Chen L (2014) Identification of bacterial community composition in freshwater aquaculture system farming of Litopenaeus vannemei reveals distinct temperature-driven patterns. Int J Molec Sci 15:13663-13680. https://doi.org/10.3390/ ijms150813663

Treusch AH, Leininger S, Kletzin A, Schuster SC, Klenk HP, Schleper C (2005) Novel genes for nitrite reductase and Amo-related proteins indicate a role of uncultivated mesophilic Crenarchaeota in nitrogen cycling. Environ Microbiol 7:1985-1995. https://doi.org/10.1111/j.1462-2920.2005.00906.x

Urakawa H, Tajima Y, Numata Y, Tsuneda S (2008) Low temperature decreases the phylogenetic diversity of ammonia-oxidizing archaea and bacteria in aquarium biofiltration systems. Appl Environ Microbiol 74:894-900. https://doi.org/10.1128/AEM.01529-07

Walker CB, de la Torre JR, Klotz MG, Urakawa H, Pinel N, Arp DJ, BrochierArmanete C, Chain PSG, Chan PP, Gollabgir A, Hemp J, Hügler M, Karr EA, Könneke M, Shin M, Lawton TJ, Lowe T, Martens-Habbena T, SayavedraSoto LA, Lang D, Sievert SM, Rosenzweig AC, Manning G, Stahl DA (2010) Nitrosopumilus maritimus genome reveals unique mechanisms for nitrification and autotrophy in globally distributed marine Crenarchaea. Proc Natl Acad Sci USA 107:8818-8823

Wang C, Lin J, Xiao Y, Huang Z, Liu W, Weng G, Song G (2004) A preliminary study of giant grouper aquaculture technology. Aquacult Sci 23:27-29 (in Chinese)

Wang J, Zhang D, Ma J, Li B, Zhang L (2015) Nutritional components analysis and nutritive value evaluation of Epinephelus fuscoguttatus $\times$ giant grouper E. lanceolatus muscle. Trans Oceanol and Limnol 4:61-69 (in Chinese, with English abstract)

Ward BB (1987) Kinetic studies on ammonia and methane oxidation by Nitrosococcus oceanus. Arch Microbiol 147:126-133

Wood PM (1986) Nitrification as a bacterial energy source. In: Prosser II (ed) Nitrification. Special publication of the society for general microbiology, vol 20. IRL Press, Oxford

Wuchter C, Abbas B, Coolen MJL, Herfort L, van Bleijswijk J, Timmers P, Strous M, Teira E, Herndl GJ, Middelburg JJ, Schouten S, Damste JSS (2006) Archaeal nitrification in the ocean. Proc Natl Acad Sci USA 103:1231712322. https://doi.org/10.1073/pnas.0600756103

Yang C, Sun J, Xu Z, Wu B, Wu Y (2016) High density culture of the hybrid grouper Epinephelus fuscoguttatus $\times$ Epinephelus lanceolatus in recirculating aquaculture system. Fisher Moderniz 3:18-22 (in Chinese, with

\section{English abstract)}

You J, Das A, Dolan EM, Hu Z (2009) Ammonia-oxidizing archaea involved in nitrogen removal. Water Res 43:1801-1809

\section{Submit your manuscript to a SpringerOpen ${ }^{\odot}$ journal and benefit from:}

- Convenient online submission

- Rigorous peer review

- Open access: articles freely available online

- High visibility within the field

- Retaining the copyright to your article

Submit your next manuscript at $\boldsymbol{\nabla}$ springeropen.com 